\title{
UTILIZATION OF DEFATTED SESAME FLOUR IN FORMULATION OF CHICKEN SAUSAGES AND ITS EFFECT ON STORAGE STABILITY AND MICROBIAL LOAD
}

\author{
Emam, Wafaa, H. \& Mohamed, G.F. \\ Food Science \& Technology Dept., National Research Centre, Dokki, Cairo, Egypt
}

\begin{abstract}
Defatted sesame flour (DSF), as a plant protein, was used in the formulation of chicken sausages by replacement of 9 and $18 \%$ of chicken meat with equal amounts of DSF. Sensory evaluation of chicken sausages showed that sausages prepared by using $9 \%$ DSF improved the quality attributes. Addition of DSF to chicken formula markedly increased the sulphur- containing amino acids as compared with the control samples. The storage stability of the frozen sausages was investigated by following the changes occurring in total volatile bases nitrogen (TVBN), thiobarbituric acid (TBA) and microbiological load during storage. The obtained results showed that partially substitution of chicken meat with DSF caused reduction in both of the TVBN and TBA values followed by a slight increase in these values for all the samples during the frozen storage. The results of microbiological analysis showed that Coliforms, Staphylococcus aureus, Salmonella and Shigella were absent in all the tested samples.
\end{abstract}

Keywords : sausages, chicken meat, defatted sesame flour, thigh, breast, gizzard, sulphur-containing amino acids.

\section{INTRODUCTION}

Chicken farms in Egypt play a major role in the national economy. Moreover, due to the high yield of white meats, chicken farms are sharing in solving the shortage of animal proteins. On the other hand, processing of chicken meat had grown substantially, and it is now easy to find the chicken meat products on supermarkets shelves. The consumers prefer these products because of their high meat content, low shrinkage during cooking, ease of digestibility and other health aspects as well as their moderate prices.

One of the major problems facing the local sausage producers today is the formulation. It is often necessary to change sausage formulation from day to day because of the fluctuations in price and/or the availability of different quality of the raw materials. Therefore, it is worthy to find a formula which can lower the cost of the product. This could be achieved by partial replacement of the costly meat by some other ingredients that can help to reduce the cost without altering the nutritional value and palatability of sausages.

In an effort to counteract the effect of reduced fat levels and obtain acceptable products, a variety of technological procedures have been conducted including incorporation of non meat ingredients. Plant proteins had been widely used as binders and extenders in meat products to improve yields, reduce formulation costs, maintain nutritional value, enhance functional properties and decrease fat and cholesterol contents (Dexter, et al., 1993, Lin \& Keeton, 1998, Dzudie, 2000).

Legume flours, such as soybean, are commonly used to replace some meat in the meat products (Berry, et al., 1979, Cruz \& Hedrick, 1985) which had stimulated interest in the potential use of other oil seed such as defatted sesame flour (DSF) in meat products (Cruz \& Hedrick, 1985). Properties of DSF and meal had been reported by Dench, et al. (1981). Moreover, DSF is rich in protein, calcium, phosphorus, and niacin. The protein of sesame (Sesamum indicum) seeds is rich in sulfurcontaining amino acids, especially meth-ionine (Boloor Forooshan \& Markakis, 1979), and thus it can be used in food products as a protein and methionine supplement.

Defatted sesame flour and/or meal was used in fortifying some foods (Bressani, et al., 1963 \& Rooney, et al., 1972) and formulating high protein beverages (Jaffe \& Chavez, 1971). However, very few work had been done on the 
use of DSF in meat products. Cruz \& Hedrick (1985) successfully used DSF in the production of fermented salami without negative effect upon sensory attributes. Therefore, the objective of the present study was to evaluate the feasibility of using DSF in the formulation of cooked, smoked, frozen chicken sausages, with the assessment of their sensory, chemical and microbiological storage stability.

\section{MATERIALS AND METHODS}

\section{Materials :}

Ten Kgs of sesame seeds (Sesamum indicum) were obtained in, June 2002, from Ministry of Agriculture, Egypt. Defatting was carried out as described by Morcos, et al. (1981).

Chickens with an average weight of 3-3.5 $\mathrm{kg}$ were obtained from a local market in Giza, Egypt. The obtained chickens were slaughtered, bled for 5 minutes, scalded for 1 minute at $90^{\circ} \mathrm{C}$, plucked by hand, eviscerated, skinned, deboned and divided into three parts (breast, thigh and gizzards). Each part was separately minced three times using an electrical meat mincer. The minced samples were used to prepare three kinds of chicken sausages, i.e., thigh, breast and gizzards sausages.

Preparation of sausages : Three kinds of sausages were prepared according to the recipe of Henrickson (1978) and El-Wakeil, et al. (1994). Two formulations were prepared for each sausage kind by replacement of 9 and $18 \%$ of chicken meat with equal amounts of DSF. Thus, a total of 9 formulations were prepared. The prepared samples and their symbols were recorded in Table (1). The following ingredients were added: $0.6 \%$

Table 1: The samples prepared in the present study and their symbols.

\begin{tabular}{ll}
\hline Samples & Symbol \\
\hline Defatted Sesame Flour & DSF \\
Chicken Breast Sausage, Control & CBSC \\
Chicken Breast Sausage, Containing 9\% DSF & CBS9 \\
Chicken Breast Sausage, Containing 18\% DSF & CBS18 \\
Chicken Thigh Sausage, Control & CTSC \\
Chicken Thigh Sausage, Containing 9\% DSF & CTS 9 \\
Chicken Thigh Sausage, Containing 18\% DSF & CTS 18 \\
Chicken Gizzard Sausage, Control & CGSC \\
Chicken Gizzard Sausage, Containing 9\% DSF & CGS 9 \\
Chicken Gizzard Sausage, Containing 18\% DSF & CGS 18 \\
\hline
\end{tabular}

tri sodium poly phosphate, $1.2 \%$ sodium chloride, $5.0 \%$ casien, $1.67 \%$ starch, $0.17 \%$ ascorbic acid, $3.33 \%$ fresh onion, $1.67 \%$ fresh garlic and $1.0 \%$ fine powdered spices mixture for each prepared sample. The sausage blends were mixed well for 5-10 minutes in a stainless steel vessel using a ladle. The sausage mix was stuffed into natural mutton casings, linked at 50-75 $\mathrm{mm}$ intervals and washed. Sausage samples were subjected to cooking in boiling water at $85-95^{\circ} \mathrm{C}$ for six minutes and dried at room temperature for 30 minutes. The cooked sausages were smoked in a smokehouse at $74^{\circ} \mathrm{C}$ and $68 \%$ relative humidity for $1.5 \mathrm{hr}$. The sausages were removed from the smokehouse, chilled at $4^{\circ} \mathrm{C}$, vacuum packaged and stored at $-18^{\circ} \mathrm{C}$ for 30 days. Fresh samples (at the time of packing) were subjected to sensory evaluation, chemical and microbilogical analysis. Frozen samples were withdrawn after 15 and 30 days for storage stability evaluation and microbiological inspection.

Sensory evaluation : Sensory evaluation was carried out by semi-trained judges using a 10 point hedonic scale rating for colour, odour, taste, juiciness, tenderness, and acceptability (Watts, et al., 1989). The rank method of statistical analysis was applied for test of the significance find the preferences (Snedecor \& Cochran, 1979).

Chemical analysis : Gross chemical composition was determined according to the AOAC (1990) methods. Amino acid content was determined as described by Moore, et al. (1958) using a Beckman Amino Acid Analyzer $119 \mathrm{Ch}$. Thiobarbituric Acid value (TBA) was determined as described by Vyncke (1970) and Lemon (1975) as mg malonaldehyde/kg on dry weight basis. Total volatile basic nitrogen (TVBN) was performed according to the method of Vyncke (1989) and expressed as $\mathrm{mg} / 100 \mathrm{~g}$ sample on dry weight basis.

Enumeration of bacteria : Total bacterial count, aerobic sporefor-mirs, Coliforms, Staphylococci, Salmonella and Shigella were enumerated at 0 -time and every 15 days during the storage period. Total bacterial count (TBC) was determined using plate count 
agar (Difco). Aerobic spore former bacteria (SFB) were determined according to Wahab (1985). Coliform bacterial count were determined according to Harrigan \& Margaret (1966) using violet red bile agar medium. Staphylococci were determined according to Baird-Parker (1962) using Baird-Parker's medium. Salmonella and Shigella were detected according to FAO/WHO (1979).

Colour evaluation : The sausage samples were cut in half and the colour of the flat surface was measured using a Hunter lab U1trascan reflectance spectrophotometer (Hunt lab, D25-L, Reston, VA, U.S.A). Five measurements were carried out on each sample. Luminance ( $\mathrm{L}$ value), redness (a value) and yellowness (b value) were measured.

\section{RESULTS AND DISCUSSION}

Sensory evaluation: Sensory characteristics of freshly cooked smoked chicken sausage samples as affected by defatted sesame flour (DSF) addition were given in Table (2). Concerning breast sausages, addition of $9 \%$

Table 2: Sensory characteristics of cooked- smoked chicken sausage as affected by defatted sesame flour ( DSF) addition.

\begin{tabular}{lcccccc}
\hline Samples* & Colour & Odour & Taste & Juiciness & Tenderness & Acceptability \\
\hline CBSC & 7.4 & $7.8^{2}$ & $7.8^{\mathrm{a}}$ & 7.3 & $7.2^{2}$ & $7.3^{\mathrm{b}}$ \\
CBS9 & $7.9^{\mathrm{a}}$ & $7.8^{\mathrm{a}}$ & $8.2^{\mathrm{a}}$ & 7.4 & 7.3 & $7.9^{\mathrm{a}}$ \\
CBS18 & 7.1 & $7.2^{\mathrm{a}}$ & $6.2^{\mathrm{b}}$ & $6.9^{\mathrm{a}}$ & 6.8 & $6.1^{\mathrm{c}}$ \\
CTSC & $6.3^{\mathrm{b}}$ & $7.5^{\mathrm{a}}$ & $7.5^{\mathrm{a}}$ & $7.3^{\mathrm{a}}$ & $7.2^{\mathrm{a}}$ & $7.6^{\mathrm{b}}$ \\
CTS9 & $7.5^{\mathrm{a}}$ & $7.8^{\mathrm{a}}$ & $8.0^{\mathrm{a}}$ & $7.3^{\mathrm{a}}$ & $7.3^{\mathrm{a}}$ & $8.3^{\mathrm{a}}$ \\
CTS18 & $5.9^{\mathrm{b}}$ & $6.7^{\mathrm{b}}$ & $6.2^{\mathrm{b}}$ & $6.7^{\mathrm{b}}$ & $6.5^{\mathrm{b}}$ & $6.3^{\mathrm{c}}$ \\
CGSC & $7.5^{\mathrm{a}}$ & $7.9^{\mathrm{a}}$ & $7.7^{\mathrm{a}}$ & $7.7^{\mathrm{a}}$ & $7.9^{\mathrm{a}}$ & $7.7^{\mathrm{a}}$ \\
CGS9 & $7.0^{\mathrm{a}}$ & $7.0^{\mathrm{b}}$ & $7.8^{\mathrm{a}}$ & $6.8^{\mathrm{b}}$ & $7.2^{\mathrm{b}}$ & $7.9^{\mathrm{a}}$ \\
CGS18 & $6.4^{\mathrm{b}}$ & $6.4^{\mathrm{c}}$ & $6.1^{\mathrm{b}}$ & $6.2^{\mathrm{c}}$ & $6.8^{\mathrm{b}}$ & $5.7^{\mathrm{b}}$ \\
\hline
\end{tabular}

* Refer to Table (1).

${ }_{a, b, c}$ Means having different letter exponents are significantly different $(p<0.05)$

DSF numerically improved the scores of all the tested properties. The improvement was insignificant $(\mathrm{p}<0.05)$ except for acceptability where a significant $(\mathrm{p}<0.05)$ difference was recorded between CBS9 and CBSC. On contrary, incorporation of $18 \%$ DSF led to decrease the organoleptic scores of all the tested parameters. The decrement was insignificant $(p<0.05)$ except for both taste and acceptability where a significant $(\mathrm{p}<0.05)$ differences were pronounced between CBS18 and CBSC. Similar observation could be given for thigh sausages, nevertheless, significant $(\mathrm{p}<0.05)$ differences were recorded between CTS18 and CTSC with respect to all the tested properties.

Regarding gizzard sausages, addition of DSF at a proportion of $9 \%$ numerically decreased the organoleptic scores, and the decrement was significant $(p<0.05)$ for odour, juiciness and tenderness. More decrement was occurred by elevating the DSF proportion up to $18 \%$ where significant $(p<0.05)$ differences appeared for all the tested properties between the incorporated sample (CGS18) and the control (CFSC).

Chemical composition : Table (3) shows the approximate chemical composition of the different smoked chicken sausage samples. It could be noticed that increasing of defatted sesame flour (DSF) in sausage preparation to $18 \%$ led to decrease the moisture and fat contents and increased both of the protein and ash contents. These results are in agreement with the results reported by Morcos, et al. (1981).

Amino acid composition : The amino acid composition (calculated as $\mathrm{g} / 100 \mathrm{~g}$ protein) of the sausage samples formulated from chicken meat (controls) and those manufactured by adding different levels of DSF to chicken meat (treated samples) are shown in Table (4). The results clearly indicated that the essential amino acid contents of all kinds of the samples were higher than those of $\mathrm{FAO} / \mathrm{WHO}$ (1979) pattern. Data indicated that threonine was considered to be the first limiting amino acid in all samples, while phenylalanine was the second limiting amino acid for most of the samples. The addition of DSF to chicken sausage formula led to increase the content of these amino acids in the samples due to the high content of DSF from these amino acids. From the same results, it could also be noticed that sausage formulated with $18 \%$ DSF was higher in sulphur-containing amino acids compared with 
the control and those containing 9\% DSF due to the high content of DSF from sulphurcontaining amino acids (Morcos, et al., 1981). by adding DSF contained lower amount of animal protein compared to the control samples. On the other hand, the TVBN content

Table 3: Chemical composition of cooked - smoked chicken sausage as affected by defatted sesame flour (DSF) addition (on dry weight basis).

\begin{tabular}{lcccccc}
\hline \multirow{2}{*}{ Sample* } & \multicolumn{7}{c}{ Chemical composition (\%) } \\
\cline { 2 - 7 } & Moisture & Protein & Fat & Ash & Fiber & N-free extract** \\
\hline DSF & 8.00 & 53.70 & 1.63 & 3.26 & 3.26 & 38.15 \\
CBSC & 65.10 & 42.44 & 50.72 & 3.73 & 0.03 & 3.08 \\
CBS9 & 60.00 & 43.45 & 46.31 & 3.68 & 0.32 & 6.24 \\
CBS18 & 54.82 & 44.47 & 41.88 & 3.65 & 0.62 & 9.38 \\
CTSC & 62.60 & 41.52 & 50.88 & 3.21 & 0.11 & 4.28 \\
CTS9 & 60.72 & 42.61 & 46.45 & 3.21 & 0.39 & 7.34 \\
CTS18 & 52.77 & 43.62 & 42.01 & 3.22 & 0.68 & 10.37 \\
CGSC & 59.51 & 32.60 & 56.61 & 6.02 & 2.22 & 2.54 \\
CGS9 & 45.87 & 34.50 & 51.67 & 5.78 & 2.31 & 5.74 \\
CGS18 & 50.24 & 36.40 & 46.71 & 5.54 & 2.41 & 8.94 \\
\hline
\end{tabular}

* Refer to Table (1)

** By differences

Table 4: Amino acid* content (g/100g protein) of cooked-smoked chicken sausage as affected by defatted sesame flour (DSF) addition.

\begin{tabular}{|c|c|c|c|c|c|c|c|c|c|c|c|c|c|c|c|c|c|}
\hline \multirow{2}{*}{ Sample** } & \multicolumn{9}{|c|}{ Essential amino acids } & \multicolumn{8}{|c|}{ Non- essential amino acids } \\
\hline & Thr. & Cys. & Met. & Val. & Iso-leu. & Leu. & Tyr. & Phe. & Lys. & Ala. & Arg. & Asp. & Glu. & His. & Pro. & Ser. & Gly. \\
\hline DSF & 3.66 & 1.95 & 3.78 & 4.75 & 3.66 & 6.58 & 3.54 & 4.75 & 2.80 & 4.27 & 14.14 & 8.17 & 20.84 & 2.68 & 3.66 & 4.39 & 4.39 \\
\hline CBSC & 3.58 & 0.93 & 2.57 & 5.05 & 5.89 & 8.71 & 2.37 & 4.06 & 7.42 & 5.85 & 5.88 & 8.92 & 20.55 & 3.65 & 3.57 & 3.63 & 3.91 \\
\hline CBS9 & 3.59 & 1.03 & 2.68 & 5.03 & 5.69 & 8.52 & 2.48 & 4.13 & 7.00 & 5.70 & 6.62 & 8.86 & 20.58 & 3.56 & 3.58 & 3.70 & 3.96 \\
\hline CBS18 & 3.60 & 1.12 & 2.79 & 5.00 & 5.49 & 8.32 & 2.58 & 4.19 & 6.58 & 5.56 & 7.36 & 8.79 & 20.61 & 3.47 & 3.59 & 3.78 & 4.01 \\
\hline CTSC & 3.39 & 1.02 & 2.84 & 5.85 & 4.85 & 8.35 & 2.17 & 4.16 & 7.48 & 5.91 & 5.75 & 8.18 & 21.09 & 2.67 & 4.30 & 3.57 & 4.71 \\
\hline CTS9 & 3.42 & 1.11 & 2.92 & 5.75 & 4.74 & 8.37 & 2.30 & 4.22 & 7.49 & 5.38 & 6.50 & 8.18 & 21.07 & 2.67 & 4.24 & 3.65 & 4.69 \\
\hline CTS18 & 3.45 & 1.20 & 3.01 & 5.66 & 4.66 & 8.03 & 2.43 & 4.27 & 6.63 & 5.61 & 7.26 & 8.19 & 21.05 & 2.67 & 4.19 & 3.73 & 4.66 \\
\hline CGSC & 3.24 & 1.13 & 2.72 & 5.24 & 4.16 & 7.66 & 2.71 & 4.84 & 6.66 & 6.51 & 6.78 & 7.96 & 18.91 & 3.36 & 4.51 & 3.53 & 4.84 \\
\hline CGS9 & 3.28 & 1.21 & 2.82 & 5.20 & 4.12 & 7.56 & 2.79 & 4.83 & 6.31 & 6.30 & 7.44 & 7.98 & 19.09 & 3.30 & 4.43 & 3.61 & 4.71 \\
\hline CGS18 & 3.32 & 1.29 & 2.91 & 5.16 & 4.07 & 7.46 & 2.86 & 4.86 & 5.96 & 6.10 & 8.10 & 8.01 & 19.27 & 3.24 & 4.36 & 3.70 & 4.88 \\
\hline FAO/WHO & 4.00 & 3. & 50 & 5.00 & 4.00 & 7.00 & 1.20 & 5.60 & 5.50 & & & & & & & & \\
\hline
\end{tabular}

* From world wide abbreviation for amino acids, only three letters digits abbreviations are used.

** Refer to Table (1).

Storage stability of sausages during frozen storage : The changes occurred in both total volatile bases nitrogen compounds (TVBN) and thiobarbituric acid number (TBA) of chicken sausage samples under investigation during storage at $-18^{\circ} \mathrm{C}$ were followed up. From the results presented in Table (5), it could be noticed that TVBN contents of the samples containing DSF were lower than that recorded for the sample without DSF addition (controls). According to Hashem, et al. (1978), the sausage prepared was increased in all samples with storage and the sausages formulated with $18 \%$ DSF contained the lowest value. Brake \& Fennema (1999) reported that TVBN increased in meat products throughout storage due to the effect of microorganisms as well as autolysis processes indicated some protein breakdown by enzymes, which were not completely inactivated during frozen storage.

Thiobarbituric acid number (TBA) is used as an index for measuring oxidative rancidity which takes place during storage. The 
obtained results in Table (5) show that, at 0time of storage, TBA number of samples containing DSF was the lowest as compared to the controls. Substitution of chicken meat storage (at $-18^{\circ} \mathrm{C}$ ) . The results given in Table (6) show that the total bacterial and aerobic spore former counts (cfu) were gradually decreased during storage to reach their lowest

Table 5: Changes occurred in thiobarbituric acid number (TBA) and total volatile bases nitrogen compounds (TVBN) of cooked- smoked chicken sausage during storage at $-18^{\circ} \mathrm{C}$ *

\begin{tabular}{|c|c|c|c|c|c|c|}
\hline \multirow{3}{*}{ Samples** } & \multicolumn{6}{|c|}{ Storage periods (days) } \\
\hline & \multicolumn{2}{|c|}{ 0 } & \multicolumn{2}{|c|}{15} & \multicolumn{2}{|c|}{30} \\
\hline & TBA $^{1}$ & $\mathrm{TVBN}^{2}$ & TBA & TVBN & TBA & TVBN \\
\hline CBSC & 1.214 & 19.67 & 1.298 & 22.16 & 1.366 & 26.44 \\
\hline CBS9 & 1.189 & 16.97 & 1.244 & 18.98 & 1.303 & 22.31 \\
\hline CBS18 & 1.157 & 15.73 & 1.207 & 22.31 & 1.288 & 20.31 \\
\hline CTSC & 1.353 & 18.08 & 1.603 & 19.95 & 1.723 & 24.03 \\
\hline CTS9 & 1.214 & 16.85 & 1.254 & 18.11 & 1.486 & 21.22 \\
\hline CTS18 & 1.151 & 15.30 & 1.293 & 17.19 & 1.380 & 19.71 \\
\hline CGSC & 1.202 & 17.15 & 1.345 & 19.02 & 1.498 & 23.59 \\
\hline CGS9 & 1.173 & 16.15 & 1.261 & 17.77 & 1.293 & 18.99 \\
\hline CGS18 & 1.167 & 15.03 & 1.298 & 16.60 & 1.267 & 18.01 \\
\hline
\end{tabular}

with DSF caused reduction in the TBA number of the prepared sausage especially at $18 \%$ replacement, therefore, it seemed that the positive effect of the addition of DSF with different percentage was observed for all samples, this effect might be due to the presence of some natural antioxidants such as flavonoids and glycosides tocopherols in DSF which caused reduction of lipid oxidation and consequently reduced TBA number (Ziprin, et al., 1981). The TBA number of sausages prepared from chicken thigh was higher than the other samples, where chicken thigh had high fat content. Moreover, sausages formulated from chicken meat had slightly higher TBA number than those formulated from chicken gizzard, this might be due to the higher percentage of unsaturated fatty acids in chicken meat compared to chicken gizzard (Ang, 1986).

During frozen storage, a slight increase in TBA number was observed for all sausage samples which indicates that some lipid oxidation have been taken place during storage. These results agree with the findings reported by El-Wakeil, et al. (1994).

Microbiological aspects of sausage samples : All samples were subjected to microbiological analysis at 0 -time and during number at the end of storage period. It seemed that both total bacterial and spore former counts were affected by heating treatment during sausage processing and also decreased as the storage time was elongated (30 days) which could be due to the lethal effect of frozen storage (Amar, et al., 1988, El- Shawaf, 1990).

Coliforms, Staphylococcus aureus, Salmonella and Shigella were absent in all the tested samples either the fresh (0-time) or during storage at $-18^{\circ} \mathrm{C}$ as a result of the hygienic conditions followed during the preparation and storage.

Colour evaluation of sausage samples during frozen storage : The $\mathrm{L}$, $\mathrm{a}$ and $\mathrm{b}$ colour parameters of the sausages are given in Table (7). The obtained results show a variation in $\mathrm{L}$, $\mathrm{a}$ and $\mathrm{b}$ values among different sausage samples due to the addition of DSF which caused a slight lighter colour. Sausage samples manufactured from thigh and breast had a white appearance, while those manufactured from gizzard appeared a little offwhite and higher darkness. On the other hand, samples containing the higher DSF proportion $(18 \%)$ had a high yellow colour. The Hunter colour values of the control sausage sample were higher in (L) and (a) values than 
the other sausage samples, while yellowness (b value) of the control was the lowest as compared to the other samples.

It could be noticed that $L$ value of luminance and therefore the lightness and yellowness (b) value of the tested samples increased result of reduced total bacterial counts, and the incorporation of DSF was detected. Yet, during the frozen storage slight increase in TBA value was observed for all sausages. Also, sausage formulated with chicken meat had slightly higher TBA values than that formulated with gizzards.

Table 6: Microbial aspects of cooked-smoked chicken sausage samples during storage at $-18^{\circ} \mathrm{C}$

\begin{tabular}{lcccccc}
\hline & \multicolumn{7}{c}{ Storage period (days) } \\
\cline { 2 - 8 } Samples* & \multicolumn{7}{c}{$\mathbf{0}$} & \multicolumn{1}{c}{$\mathbf{1 5}$} & \multicolumn{3}{c}{$\mathbf{3 0}$} \\
\cline { 2 - 7 } & cfu x 10 & S. F. B. & cfu x 10 & S. F. B. & cfu x10 & S. F. B. \\
\hline CBSC & 15 & 50 & 1.0 & 40 & 1.0 & 30 \\
CBS9 & 1.2 & 30 & 1.0 & $>30$ & 1.0 & $>30$ \\
CBS18 & 13 & 50 & 1.0 & 40 & 1.0 & $>30$ \\
CTSC & 9.0 & 40 & 4.0 & 100 & 4.0 & $>30$ \\
CTS9 & 2.5 & 30 & 1.0 & $>30$ & 1.0 & 50 \\
CTS18 & 8.0 & 50 & 2.0 & 40 & 4.0 & 30 \\
CGSC & 30 & 100 & 30 & 30 & 20 & 80 \\
CGS9 & 70 & 100 & 17 & 100 & 13 & 80 \\
CGS18 & 10 & 40 & 7.0 & 30 & 2.0 & $>30$ \\
\hline
\end{tabular}

* Refer to Table (1) cfu =colony forming units

S. F. B.: Spore forming bacteria.

Table (7): Colour* changes of cooked-smoked chicken sausage as affected by both DSF addition and storage period $\left(\right.$ at $\left.-18^{\circ} \mathrm{C}\right)$.

\begin{tabular}{|c|c|c|c|c|c|c|c|c|c|}
\hline \multirow{3}{*}{ Samples** } & \multicolumn{9}{|c|}{ Storage periods (days) } \\
\hline & \multicolumn{3}{|c|}{ 0 } & \multicolumn{3}{|c|}{15} & \multicolumn{3}{|c|}{30} \\
\hline & $\mathbf{L}$ & $\mathbf{a}$ & b & $\mathbf{L}$ & $\mathbf{a}$ & b & $\mathbf{L}$ & $\mathbf{a}$ & $\mathbf{b}$ \\
\hline CBSC & 49.4 & 7.5 & 8.9 & 51.3 & 7.2 & 9.6 & 52.4 & 6.5 & 10.9 \\
\hline CBS9 & 50.8 & 6.4 & 10.5 & 52.2 & 6.0 & 10.7 & 53.1 & 5.7 & 11.8 \\
\hline CBS18 & 52.4 & 5.9 & 13.4 & 53.6 & 5.1 & 13.9 & 53.9 & 4.8 & 14.3 \\
\hline CTSC & 52.6 & 8.4 & 9.5 & 53.2 & 8.2 & 10.9 & 55.1 & 7.9 & 12.6 \\
\hline CTS9 & 52.7 & 7.2 & 11.0 & 54.1 & 7.3 & 11.8 & 54.6 & 5.6 & 13.7 \\
\hline CTS 18 & 53.2 & 6.7 & 14.8 & 54.9 & 5.9 & 15.5 & 55.2 & 6.1 & 16.6 \\
\hline CGSC & 55.8 & 9.3 & 12.6 & 56.4 & 8.9 & 13.3 & 58.2 & 8.4 & 14.6 \\
\hline CGS9 & 53.0 & 8.1 & 13.4 & 55.1 & 7.9 & 14.3 & 55.6 & 7.5 & 16.1 \\
\hline CGS18 & 51.7 & 8.1 & 15.0 & 57.2 & 7.9 & 15.6 & 53.9 & 7.5 & 17.3 \\
\hline
\end{tabular}

* Hunter Lab., mean of three readings.

\section{REFERENCES}

redness value (a) decreased. This was probably due to the changes in the oxidation state of haem pigments, or the interaction between amines and sugars in Maillard reactions (Hastings, 1989).

Conclusion : The present results showed that the addition of defatted sesame flour helps to produce chicken sausage of lower price and better nutritive value without altering the quality attributes. The breakdown of proteins and fats during frozen storage as a
Amar, K.A., Gouda, M.S. \& Metwalli, S.M. 1988. The effect of frozen storage on some qualities of cow meat. J. Agric. Sci. Mansoura Univ., 13: 2284-2290.

Ang, C.Y.W. 1986. Effect of further processing and storage of mechanically deboned chicken on proximate composition, thiamine, riboflavin and TBA values. J. Food Sci., 51: 861-865.

AOAC 1990. Official Methods of Analytical Chemists. Published by the Association of 
Official Analytical Chemists, Inc. Suite 400. 2200 Wilson Boulevard, Arlington, Virginia 22201 U.S.A.

Baird-Parker, A.C. 1962. An improved diagnostic and selective medium for isolating coagulase (positive Staphylococci). J. Appl. Bact., 25:12-15.

Berry, B.W., Gross, H.R., Joseph, A.I., Wagnei, S.B. \& Mega, J.A. 1979. Sensory and physical measurements of dry fermented salami prepared with mechanically proc-essed beef product and structured soy protein fiber. $J$. Food Sci., 44: 468-474.

Boloor Forooshan, M. \& Markakis, P. 1979. Protein supplementation of navy beans with sesame. J. Food Sci., 44: 390-391.

Brake, N.C. \& Fennema, O.R. 1999. Lipolysis and lipid oxidation in frozen minced mackerel as related to glass tensition, molecular diffusion and presence of gelatin. J. Food Sci., 64: 25-32.

Bressani, R., Braham, J. \& Arroyava, G. 1963. Desarrollo de una racion Practica para la alimentacion de pollos. Usos de harina de algoden Y ajonjoli., 13: 213-216.

Cruz, O.A. \& Hedrick, H.B. 1985. Utilization of defatted sesame flour in fermented salami. J. Food Sci., 50: 1177-1178.

Dench, J.E., Rivas, N. \& Caygill, J.C. 1981. Selected functional properties of sesame (Sesamum Indicum L.) flour and protein isolated. J. Sci. Food Agr., 32: 557-561.

Dexter, D.R., Sofos, J.N. \& Schmidt, G.R. 1993. Quality characteristics of turkey bologna formulated with carrageenan, starch, milk and soy protein. J. Muscle Foods, 4: 207223.

Dzudie, T. 2000. Physico-chemical and theological properties of low-fat, highadded water beef sausage extended with common bean flour. J. Muscles foods, 11: 129-142.

El-Shawaf, A.M. 1990. Microbial Studies on Aflatoxins in Meat Products. Ph.D. Thesis, Faculty of Agriculture, Mansoura University, Mansoura, Egypt.

El-Wakeil, F.A., Shadia, M.S. \& Nadia, A.S. 1994. Evaluation of chemical and nutritional properties of chicken sausages extended with soy and sunflower flour. Egypt. J. Food Sci., 22: 271-291.

FAO/WHO 1979. Report of a joint FAO/WHO Expert Consultations on microbiological specifications for food. Rome (EC/ Microbiol/79 Report 4).
Harrigan, W.F. \& Margaret, E.M. 1966. Laboratory Methods in Microbiology. Academic Press, London and New York.

Hashem, H.A., Shaheen, A., El-Damaty, E.M., ElDushlouty, M.S. \& Ameen, M.A. 1978. Quality indices and bacteriological changes occurring in sausage as prepared with meat substitutes of plant origin. Egypt. J. Food Sci., 6: 83-90

Hastings, R.J. 1989. Comparison of the properties of gels derived from cod surimi and from unwashed and once-washed cod mince. Inter. J. Food Sci. and Techn., 24: 93-102.

Henrickson, R.L. 1978. Meat, Poultry and Seafood Technology. Prentice-Hall, Inc., Englewood cliffs, New Jersey 07632, Chap., 16, pp. 213.

Jaffe, W.G. \& Chavez, J.F. 1971. El Posible uso de la harina de ajonjoil Para fines comestibles. Arch. Latino Amer. Nutr., 11: 31-34.

Lemon, D.W. 1975. An improved TBA test for rancidity. New Series Circular No.5.

Lin, K. \& Keeton, T.T. 1998. Textural and physicochemical properties of low-fat, precooked ground beef patties containing carrageenan and sodium aliginate. J. Food Sci., 63: 571-574.

Moore, S., Spachman, D.H. \& Stein, W. 1958. Chromatography of amino acid on salphonated polytrene resins. Anal. Chem., 30: 1185- 1189.

Morcos, S.R., Elhawary, Z. \& Gabrial, G.N. 1981. Protein-rich food mixture for feeding the young in Egypt. 1. Formulation. Zeitschrift für Ernährungs-wissen-schaft, 20: 275-28

Rooney, L.W., Gustafson, C.B., Clark, S.P. \& Cater, C.M. 1972. Comparison of the baking properties of several oil seed flours. J. Food Sci., 37:14-17.

Snedecor, G.W. \& Cochran, W.G. 1979. Statistical Methods. The Iowa State Univ. press, Ames, IA.

Vyncke, W. 1970. Direct determination of the thiobarbituric acid value in trichloro-acetic acid extracts of fish as a measure of oxidative rancidity. Fette. Seinfen, 72: 1084-1087.

Vyncke, W. 1989. Determination of volatile basic in fish. Associatoin (W.E.F.T.A.), ZLebensm ubters., 113: 113-116.

Wahab, G.A.M. 1985 Effect of Gamma Radiation on Some Microorganisms Usually Present in Milk. M.Sc. Thesis, Fac. of Agric., Zagazig University, Zagazig, Egypt. 
Watts, B.M., Yamaki, G.L., Jeffery, L.E. \& Elias, L.G. 1989. Basic sensory methods for food evaluation. $1^{\text {st }}$ Edition, The inter-national Development Research Center Publ., Ottawa, Canada.
Ziprin, Y.A., Rhee, K.S., Carpenter, Z.L., Hostler, R.L., Terrell, R.N. \& Rhee, K.C. 1981. Gland less cottonseed, peanut and soy protein ingredients in ground beef patties, Effects on rancidity and other quality factors. J. Food Sci., 46: 58-61.

\title{
استخدام دقيق السمسم منزوع الدهن في خلطة سجق الدجاج وتأثير ذلك على ثبات المنتج و محتواه الميكروبى أثناء التخزين
}

\author{
وفاء حسين إملم - جمل فؤاد محمد \\ قسم الصناعلت الغذائية - المركز القومع للبحوث - الدقى - الجيزة
}

قم استخدلم دقيق السمصم مذزوع الدهن فى إنتاجسجق الدجاج وذك بلستبدل 9 ، 1 ا\% من كمية اللهم الدلخل

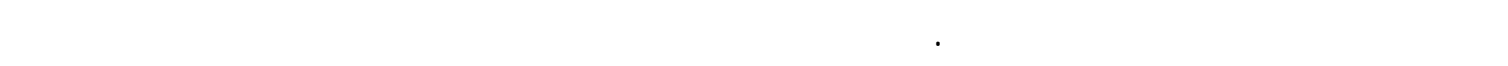

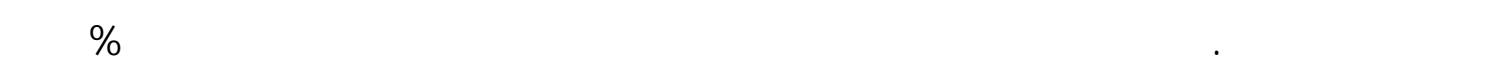

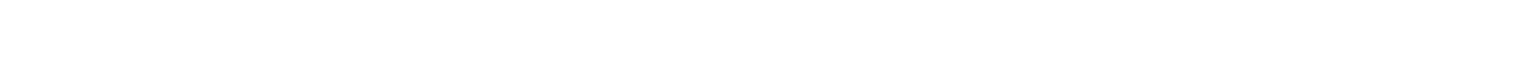

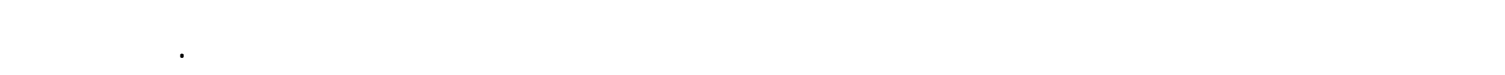

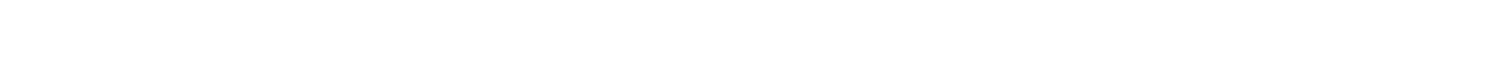

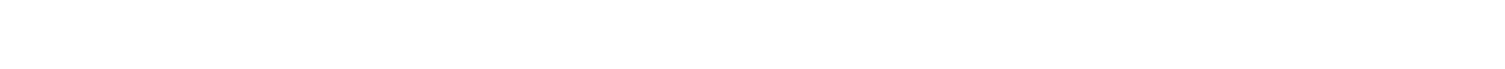

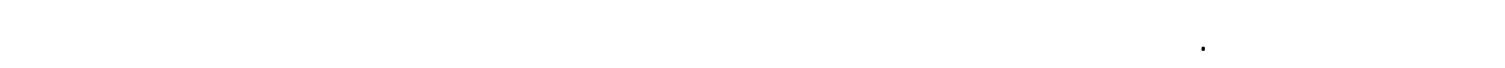
المختبرة وهي المالمونيللا و الثجيللامع النخفاض عد الميكروبك المكونة المستعمرات. 